\title{
Pengelolaan Wakaf Uang Pada Lembaga Pusat Pengelolaan Dana Sosial Dalam Bidang Pendidikan di Universitas Airlangga Surabaya
}

\author{
Alfian Rico Firmansyah ${ }^{1 *}$ \\ Universitas Muhammadiyah Sidoarjo*1 \\ *1email: ricodelta89@gmail.com
}

\begin{abstract}
One of the institutions in Islam that has a great contribution and potential to the welfare of Muslims in waqf. Waqf is also a religious practice which is closely related to the welfare of the people. One of the sources of Islamic finance which has the potential to develop the economy of the people is waqf. Even though the potential of waqf in Indonesia is quite large, the management of waqf in Indonesia is still said to be underdeveloped when compared to other countries even though it has such a large contribution. With the potential for land waqf which is very broad, which should have and save a very large economic potential, currently it has not been managed optimally. However, the waqf assets in Indonesia in the form of land in the management and allocation are still allocated for mosques at $44.64 \%$, musholla $28.23 \%$, schools $10.63 \%$, social $8.58 \%$ and funerals $4.50 \%$.
\end{abstract}

Keywords : Waqf, Productive, Umat, Potential Waqf.

\section{Abstrak}

Salah satu institusi dalam Islam yang memiliki kontribusi dan potensi yang besar terhadap kesejahteraan umat Islam dalam wakaf. Wakaf juga merupakan salah satu ibadah maliyah yang erat kaitannya dengan kesejahteraan umat. Salah satu instrument sumber keuangan Islam dimana memiliki potensi dalam mengembangkan perekonomian umat adalah wakaf. Meskipun potensi wakaf di Indonesia cukup besar tetapi pengelolaan wakaf di Indonesia masih dikatakan belum berkembang apabila dibandingkan dengan negara lain meskipun mempunyai sumbangsih begitu besar .

Artikel Info

Received:

20 February 2021

Revised:

04 April 2021

Accepted:

02 June 2021

Published:

10 June 2021 


\section{INTIQAD: JURNAL AGAMA DAN PENDIDIKAN ISLAM}

ISSN 1979-9950 (print) || ISSN 2598-0033 (online), http://jurnal.umsu.ac.id/index.php/intiqad

DOI: intiqad.v\%vi\%i.6390

Vol. 13, No. 1 (June 2021)

Dengan potensi wakaf tanah yang sangat luas yang seharusnya memiliki dan menyimpan potensi ekonomi sangat besar saat ini belum dikelola secara maksimal . Namun, harta wakaf di indonesia yang berbentuk tanah dalam pengelolaan dan peruntukannya masih di peruntukkan untuk masjid sebesar 44,64 \%, musholla 28,23\%, sekolah $10,63 \%$, Sosial $8,58 \%$ dan pemakaman 4,50 \%

\section{Kata Kunci : Wakaf, Produktif, Umat, Potensi Wakaf.}

\section{A. Pendahuluan}

Saat ini wakaf menjadi perhatian dunia dimana melalui wakaf dapat dimanfaatkan dan menjadi solusi atas segala permasalahan krisis dunia yang terjadi (Kuncorowati, Achsani, \& Hafidhuddin, 2018). Indonesia merupakan Negara dengan pemeluk agama Islam terbesar di seluruh dunia dengan jumlah pemeluk sebesar 209,1 juta pemeluk Islam (Kusnandar, 2019) Dengan besarnya jumlah pemeluk muslim di Indonesia menjadikan potensi wakaf Indonesia sangat besar (Ariansyah\&Kurnia, 2018). Wakaf tanah harus dikelola secara efektif dan efisien dan sesuai dengan prinsip syariah maka akan memiliki potensi dan manfaat ekonomi yang besar (Salmawati, 2018). Wakaf sudah banyak dikenal dan diimplementasikan oleh umat Islam dari awal Islam masuk ke Indonesia dan saat ini menjadi salah satu penunjang pengembangan agama dan umat Islam (Yolleng, 2018). Besarnya potensi wakaf di Indonesia dapat dijadikan peluang tetapi disisi lain juga terdapat tantangan dalam mewujudkan tujuan pengelolaan wakaf itu sendiri (Efendi, 2018). Terdapat banyak wakaf yang dipraktikkan di Indonesia salah satu wakaf yang lama di praktikan di Indonesia adalah wakaf tanah (Tulab, 2018). Potensi wakaf tanah di Indonesia cukup besar di mana wakaf tanah mempunyai total luas sebesar 50.031,65 Ha yang tersebar ke dalam 370.436 (siwak, 2018). 


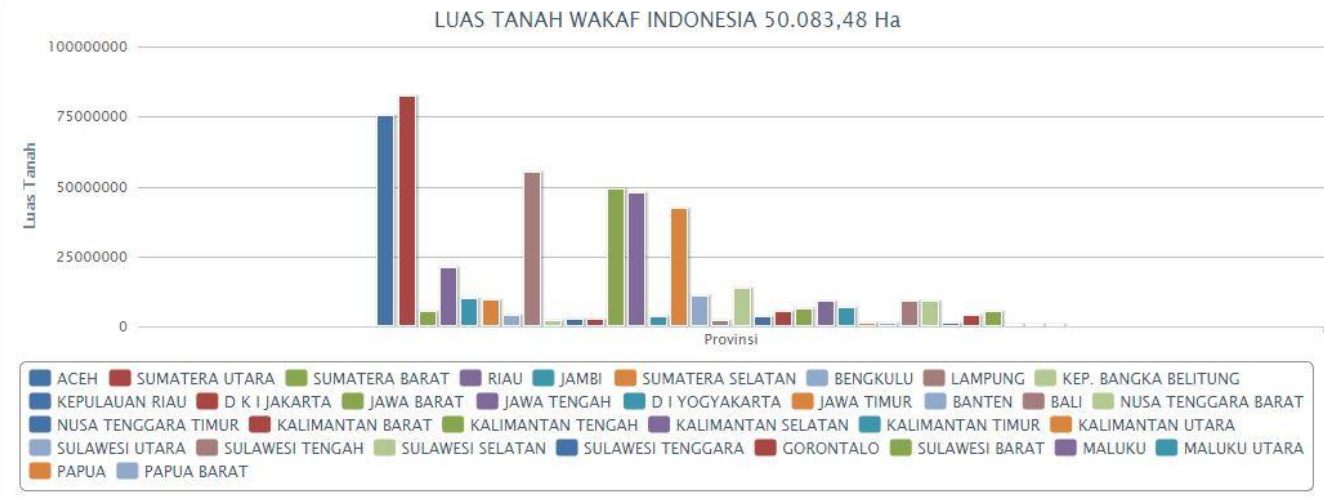

\section{Gambar 1. Data Wakaf di Indoensia (Sumber: Siwak Kemenag)}

Meskipun potensi wakaf di Indonesia cukup besar tetapi pengelolaan wakaf di Indonesia masih dikatakan belum berkembang apabila dibandingkan dengan negara lain meskipun mempunyai sumbangsih begitu besar (Rafiqi, 2018). Dengan potensi wakaf tanah yang sangat luas yang seharusnya memiliki dan menyimpan potensi ekonomi sangat besar saat ini belum dikelola secara maksimal (Afif, 2018). Namun, harta wakaf di indonesia yang berbentuk tanah dalam pengelolaan dan peruntukannya masih di peruntukkan untuk masjid sebesar 44,64\%, musholla $28,23 \%$, sekolah $10,63 \%$, Sosial 8,58 $\%$ dan pemakaman $4,50 \%$.

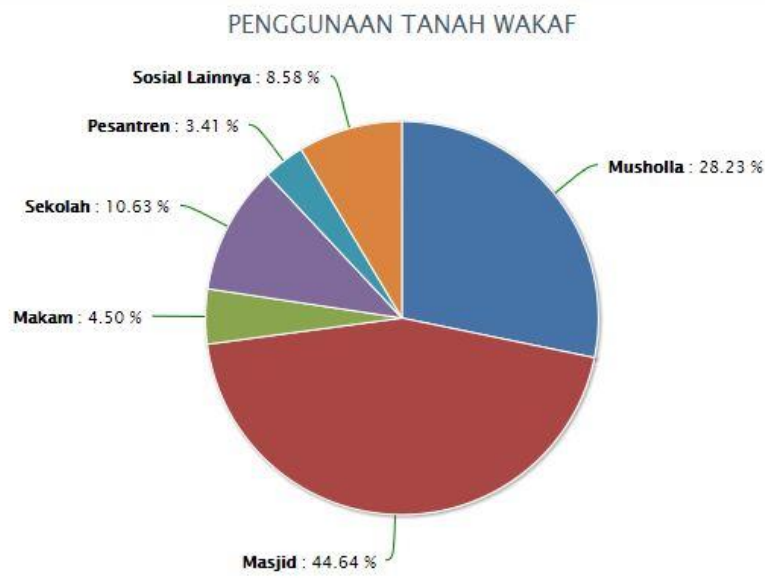

Gambar 2. Penggunaan Tanah Wakaf di Indonesia (Sumber: Sistem Wakaf Kemenag)

Copyright $\odot$ 2021. Intiqad: Jurnal Agama dan Pendidikan Islam. This is an open acces article under the CC-BY-SA lisence (https://creativecommons.org/licenses/by-sa/4.0/). 


\section{INTIQAD: JURNAL AGAMA DAN PENDIDIKAN ISLAM}

ISSN 1979-9950 (print) || ISSN 2598-0033 (online), http://jurnal.umsu.ac.id/index.php/intiqad

DOI: intiqad.v\%vi\%i.6390

Vol. 13, No. 1 (June 2021)

Dari data di atas menunjukkan bahwa peruntukan wakaf tanah di Indonesia masih belum mengarah pada aplikasi yang produktif. selain itu dari data di atas apabila pemanfaatan wakaf ditinjau dari segi sosial khususnya kepentingan peribadatan memang dapat dikatakan efektif tetapi apabila ditinjau dari segi ekonomi maka dampaknya akan kurang berpengaruh (Rajafi, 2018). Pemanfaatan wakaf diatas justru akan merugikan masayarakat dimana akan menimbulkan biaya yang harus dikeluarkan minimal yaitu biaya pemeliharaan (Rochmiyatun, 2018). Oleh karena itu wakaf harus dikelola secara produktif sehingga dapat bermanfaat bagi kepentingan umat.

Dalam beberapa tahun terakhir konsep wakaf di Indonesia terus berkembang dan diimplementasikan di Indonesia. Wakaf uang hadir sebagai suatu konsep terbaru dalam praktik wakaf di Indonesia yang saat ini mulai dipraktikkan di Indonesia. Secara umum nadzir selaku pengelola wakaf uang diharuskan bekerja sama dengan Lembaga Keuangan Syariah Pengumpul Wakaf Uang (LKSPWU) dalam proses penghimpunan wakaf uang.

Copyright @ 2021. Intiqad: Jurnal Agama dan Pendidikan Islam. This is an open acces article under the CC-BY-SA lisence (https://creativecommons.org/licenses/by-sa/4.0/).
Dana wakaf uang yang terkumpul selanjutnya akan diinvestasikan pada sektor riel atau digunakan dalam mendirikan suatu usaha dimana dari ushaa tersebut hasilnya akan diberikan kepada mauquf alaih dan hak nadzhir, Berdasarkan konsep diatas dapat dipahami bahwa peruntukan untuk mauquf alaih cukup tinggi yaitu $90 \%$.

Pemerintah selaku otoritas terkait juga telah mengatur mengenai wakaf uang dimana telah diatur dalam Undang - Undang Nomor 41 Tahun 2004 yang mengatur mengenai wakaf dimana dalam peraturan ini dijelaskan bahwa peruntukan untuk nadzhir adalah sebesar 10\% (Senjiati, Lis Sulistiani, \& Mubarok, 2020). Konsep wakaf uang sejatinya adalah berupa penyerahan asset wakaf yang berupa uang tunai dimana harta wakaf tersebut tidak dapat digunakan selain untuk kepentingan (Zahro, 2020). Konsep wakaf seperti ini dinilai sebagai konsep yang fleksibel dikarenakan memudahkan para wakif dalam mewakafkan harta mereka (Nissa, 2017). 


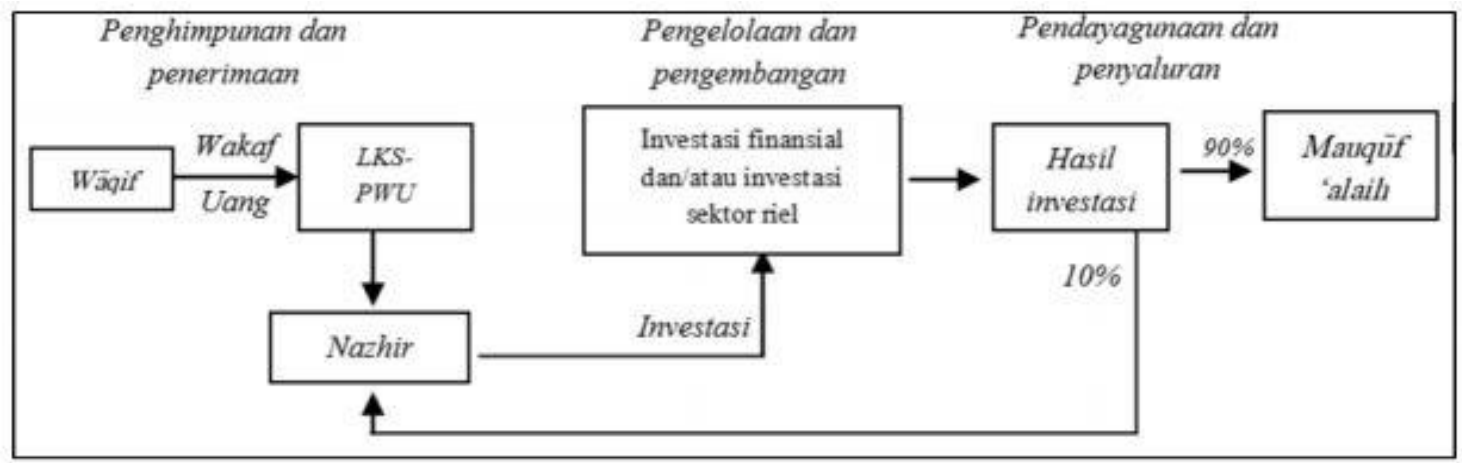

Gambar 3. Konsep Wakaf Uang (Sumber: Badan Wakaf Indonesia)

Wakaf uang dinilai memiliki potensi yang besar untuk dikembangkan bahkan konsep wakaf uang ini telah dikembangkan pada zaman Turki Usmani dimana pada saat itu dengan konsep wakaf ini dapat mendukung perekonomian Negara (Tanjung, Suhandi, \& Tanzila, 2020).

Potensi wakaf uang di Indonesia cukup tinggi dimana Badan Wakaf Indonesia memprediksi bahwa mencapai Rp120 triliun per tahun dengan asumsi ada 100 juta warga negara Indonesia mewakafkan uangnya sebesar Rp100 ribu per bulan. Selain itu apabila sekitar 20 juta umat Islam di indonesia mewakafkan hartanya sekitar Rp 1 juta per tahun maka potensi wakaf uang bisa mencapai $\mathrm{Rp} 20$ triliun (Novitasari, 2018). Dengan semakin besarnya umat yang mewakafkan hartanya maka semakin besar pula potensi wakaf uang di Indonesia. Selain itu dengan adanya digitalisasi akan memudahkan kegiatan pengumpulan dana wakaf uang melalui platform digital (Lubis \& Latifah, 2019).

Saat ini terdapat banyak nadzhir wakaf yang mengelola wakaf uang salah satunya adalah Pusat Pengelolaan Dana Sosial (PUSPAS) Universitas Airlangga. Nadzhir wakaf uang Puspas merupakan salah satu nadzir wakaf uang di bawah naungan Universitas Airlangga. Adapun hasil dari pengelolaan wakaf uang ini diperuntukkan dalam bidang pendidikan. Potensi dana wakaf uang yang dihimpun oleh nadzhir Puspas ini cukup tinggi mengingat civitas akademika Universitas Airlangga yang cukup besar. Selain masyarakat umum 
INTIQAD: JURNAL AGAMA DAN PENDIDIKAN ISLAM

ISSN 1979-9950 (print) || ISSN 2598-0033 (online), http://jurnal.umsu.ac.id/index.php/intiqad

DOI: intiqad.v\%vi\%i.6390

Vol. 13, No. 1 (June 2021) lembaga PUSPAS juga menerima wakaf dari usaha mikro yang ingin melakukan wakaf.

Dengan semakin banyak lapisan masyarakat yang melakukan wakaf maka semakin besar manffat yang akan dirasakan umat. UMKM sebagai penopang ekonomi di Indonesia sangat berpotensi sebagai peningkatan penerimaan wakaf (Oktafia, 2017).

Berdasarkan latar belakang yang telah dipaparkan sebelumnya, maka fokus dalam penelitian ini adalah menggali mengenai konsep pengelolaan wakaf uang pada lembaga Pusat Pengelolaan Dana Sosial (PUSPAS) yang diperuntukkan dalam bidang pendidikan.

\section{B. Metode Penelitian}

Berdasarkan pemaparan diatas tujuan yang ingin dicapai dalam penelitian ini adalah menganalisis pengelolaan dana wakaf pada lembaga PUSPAS.

Metode yang digunakan dalam penelitian ini adalah kualitatif dengan pendekatan studi kasus. Penulis mendapatkan data memlalui wawancara dengan pihak PUSPAS serta melakukan diskusi. Hal ini didasarkan supaya informasi yang akan diperoleh dari narasumber secara utuh. Karena dengan ini penulis dapat mengetahui keadaan yang sebenarnya yang ada di PUSPAS, selain itu penulis juga melakukan observasi dan studi kepustakaan.

Teknik pengumpulan data yang penulis gunakan dalam penelitian ini adalah dengan wawancara, observasi, dan studi kepustakaan. Dalam melakukan analisis data dilakukan dengan pengumpulan data, reduksi data, penyajian data dan penarikan kesimpulan.

\section{Hasil dan Pembahasan}

Wakaf dikenal sebagai fungsi untuk memberdayakan ekonomi umat, instrument wakaf sendiri bagi umat muslim sangat begitu besar dalam membantu kemaslahatan perekonomian, maupun di jaman dulu atau sekarang, wakaf sendiri harus menahan nilai harta nya dan perolehan lebih nya digunakan untuk kepentingan seluruh elemen masyarakat. Serta bertujuan mendapat keridhoan Allah Swt.

Ruang lingkup Wakaf untuk jangka panjang memberikan sebuah 


\section{INTIQAD: JURNAL AGAMA DAN PENDIDIKAN ISLAM}

ISSN 1979-9950 (print) || ISSN 2598-0033 (online), http://jurnal.umsu.ac.id/index.php/intiqad

DOI: intiqad.v\%vi\%i.6390

Vol. 13, No. 1 (June 2021) gambaran yang sangat menjanjikan dalam memperoleh pemanfaatan yang cukup besar selain dari pemanfaatan dari hasil wakaf tersebut, sebab Wakaf juga bisa memperluas suatu jaringan pemberi wakaf dalam perorangan maupun pada sebuah lembaga yang ingin melaksanakan kegiatan wakaf dalam dasar meningkatkan harta produktifitas harta wakaf.

Sistem pengelolahan wakaf uang merupakan hal yang menarik, karenan keuntungan dalam ivestasi yang menggunakan harta wakaf bisa dirasakan perolehan nya dan pemanfaatan nya sekaligus bisa di rasakan oleh semua masrakat Indonesia, dengan demikian diharapkan mampu memberi dampak positif dalam keharmonisan antara masyarakat kaya dan miskin.

Pusat Pengelolaan Dana Sosial Universitas atau PUSPAS Airlangga Surabaya adalah sebuah lembaga yang mengelola, menghimpun, menyalurkan bantuan sosial ke masyarakat, PUSPAS ini sebuah lembaga yang di tunjuk Universitas Airlangga Surabaya untuk mengelola wakaf uang, yang mana salah satunya untuk mngentas permasalah Copyright @ 2021. Intiqad: Jurnal Agama dan Pendidikan Islam. This is an open acces article under the CC-BY-SA lisence (https://creativecommons.org/licenses/by-sa/4.0/). pendidikan yang ada dalam lingkungan Universitas Airlangga Surabaya.

Permasalahan pendidikan tidak bisa di pandang sebelah mata perlu adanya rencana dan penanggulangan untuk menyelasaikan permasalahan pendidikan dengan Wakaf uang sebagai solusi atas terjadinya masalah pendidikan dalam lingkungan Universitas Airlangga Surabaya.

Setelah melakukan penelitian Wakaf uang pada lembaga Pusat pengelolaan dana sosial mengamati data dan berbagai informasi yang di dapat dilapangan secara konseptual sudah memenuhi standart POAC (planning, organizing, actuanting, dan controlling), berikut ini adalah penjelasan dari manajemen POAC yang dilakukan oleh PUSPAS.

\section{a. Perencanaan (planning)}

Planning adalah upaya yang dilakukan oleh pengelola PUSPAS untuk mencapai tujuan yang diinginkan. Langkah-langkah yang dilakukan oleh manajemen PUSPAS dalam rangka menuju suatu tujuan, adalah sebagai berikut.

1) Menetapkan sasaran dan tujuan 
Sasaran yang akan dituju dalam satu periode ditetapkan pada saat pembuatan planning. Penetapan target dalam pengumpulan dana wakaf atau fundrising di lingkungan kampus Universitas Airlangga.

2) Merumuskan Pelaksanaan Lembaga Pusat Pengelolaan Dana Sosial memiliki rencana dan tujuan yang sudah ditetapkan. PUSPAS mengidentifikasi keadaan lembaga saat ini dan melihat kemapuan organisasi dalam mencapai tujuan yang telah ditetapkan.

3) Merumuskan rencana alternatif

Pada Saat melakukan kegiatan PUSPAS melakukan persiapan untuk kegiatan yang akan dijalankan. Termasuk membuat rencana alternatif untuk kegitana pengumpulan dana wakaf. Jika ada staff yang berhalangan maka akan diganti oleh staff lainnya.

4) Mengembangkan Rencana

Setiap organisasi memiliki tujuan atau target yang akan dicapai dalam satu periode, begitu juga dengan PUSPAS. Pengembangan rencana yang dilakukan oleh staff PUSPAS yaitu dengan melihat potensi dari kegiatan yang dilakukan.

\section{b. Proses organisasi (organizing)}

Proses organisasi yang dilakukan oleh Pusat Pengelolaan Dana Sosial PUSPAS, akan membahas dan mempertimbangkan beberapa hal yang terkait dalam organisasi sehingga pengelompokkan kegiatan mejadi lebih efisien dan efektif. Tahapan-tahapan dalam melakukan pengelompokan pekerjaan adalah sebagai berikut:

1) Menetapkan Tugas Pengorganisasian

Tujuan Pusat Pengelolaan Dana Sosial PUSPAS sudah ditentukan sejak awal yaitu menjadi pusat penghimpunan dana wakaf yang inovatif dan terpercaya bagi seluruh masyarakat sebagai bentuk tanggung jawab UNAIR, serta menjadi lembaga pengelola dana wakaf secara transparan, dapat dipercaya, melaksanakan seluruh prosedur dengan professional dan diakui oleh masyarakat luas.

2) Menetapkan Tugas Pokok Anggota 
Pusat Pengelolaan Dana Sosial melaksanakan tanggung jawab penuh kepada Rektor. Peraturan resmi yang menjadi landasan hukum atas penugasan anggota mengacu pada Surat Keputusan Rektor Nomor 789/UN3/2017. Yaitu, devisi funding, yang mempunyai tanggung jawab untuk menghimpun dana dari masyarakat dan mencari donatur-donatur yang terdapat di lingkungan UNAIR maupun diluar kampus. Devisi pengembangan produk memiliki tanggung jawab untuk mengembangkan produk-produk wakaf uang yang ada di PUSPAS. Dan devisi penyaluran yang mana devisi ini memiliki tugas untuk menyalurkan dana wakaf dari donatur untuk pengembangan pendidikan di lingkungan UNAIR.

3) Alokasi sumber daya yang tersedia Mengatur tentang sumber daya yang terdapat di lingkungan PUSPAS, masih dipertimbangkan secara terbuka, dan dilakukan musyawarah dalam kegiatan rapat bulanan. Pada saat ini prosedur tentang sumber daya masih bersifat nonformal atau belum ada ketentuan resmi dari pihak kampus yang mengatur mengenai penggunaan sumber daya. Dalam masalah sumber daya sangat diperlukan kesadaran diri.

\section{c. Pelaksanaan ( actuanting)}

Fungsi pengarahan bertujuan untuk memberikan sifat disiplin pada staff serta memiliki fungsi untuk edukasi kepada para pekerja agar dapat bekerja sama dan bekerja secara efektif dan efisien dalam mewujudkan tujuan yang akan dicapai. Edukasi yang akan diberikan kepada setiap lembaga dengan cara meningkatkan motivasi dan bimbingan terhadap para staff, supaya mereka dapat melaksanakan tanggung jawab sesuai dengan target yang telah ditetapkan.

\section{d. Pengawasan (controlling)}

Fungi dari pengawasan pada lembaga Pusat Pengelolaan Dana Sosial untuk mengontrol kegiatan dan program kerja yang sedang dilakukan PUSPAS. Dari tahapan planning, organizing, actuanting, hal terakhir yang dilakukan adalah melakukan controlling untuk 
INTIQAD: JURNAL AGAMA DAN PENDIDIKAN ISLAM

ISSN 1979-9950 (print) || ISSN 2598-0033 (online), http://jurnal.umsu.ac.id/index.php/intiqad

DOI: intiqad.v\%vi\%i.6390

Vol. 13, No. 1 (June 2021) memastikan semua kegiatan yang dilaksanakan sudah sesuai dengan tujuan dan rencana yang telah dibuat sebelumnya.

Contoh kasus dalam pelaksanaan penggunakan empat prinsip manajemen tersebut adalah sebagai berikut.

1) Para pengurus lembaga PUSPAS melakukan rapat untuk membuat prencanaan dalam pelaksanaan pengumpulan dan penyaluran dana wakaf.

2) Setelah itu para pengurus akan saling berbagi tugas dan tanggung jawab dalam mengumpulkan dana wakaf sesuai dengan rencana yang sudah ditetapkan.

3) Selanjutnya adalah melaksanakan kegiatan penghimpunan dana wakaf yang sudah direncanakan sejak awal.

4) Selanjutnya setelah dana wakaf terkumpul maka akah dihitung terlebih dahulu, setelah itu baru kegiatan penyaluran akan dilaksanakan.

5) Kegiatan penyaluran diberikan kepada mahasiswa yang kurang mampu untuk membayar biaya kuliah.

\section{Simpulan}

Potensi wakaf uang di Indonesia sangat besar, akan tetapi belum dimanfaatkan secara maksimal. Pemanfaatan harta benda wakaf masih diperuntukkan dalam bentuk masjid, makam, dan madrasah.

Dalam lembaga PUSPAS pemanfaatan dan pengelolaan wakaf uang dilakukan secara terorganisasi. Lembaga PUSPAS menggunakan empat prinsip manajemen, yaitu perencanaan, pengorganisasian, pelaksanaan, dan pengawasan.

Dengan menerapkan empat prinsip organisasi tersebut lembaga PUSPAS dapat menghimpun dana wakaf dengan maksimal serta menyalurkan untuk kegiatan pendidikan bagi mahasiswa yang kurang mampu. Karena sudah direncanakan dan sudah terdapat tujuan sejak awal, sehingga tidak ada kesulitan saat melakukan penghimpunan dan penyaluran dana wakaf. 


\section{E. Daftar Pustaka}

Afif, A. R. S. S. (2018). Pengaruh model rekrutment karyawan badan wakaf pada kinerja pengelolaan aset umat (Studi kasus Badan Wakaf Indonesia). Jurnal Al Tijarah, 4(2), 25-35. https://doi.org/10.21111/tijarah.v4i 2.2826

Ariansyah\&Kurnia. (2018). Persepsi Masyarakat Terhadap Wakaf Sebagai Alternatif Instrumen Keuangan Publik Di Indonesia Ariansyah. Jurnal Sketsa Bisnis, 5(2), 113-122.

Efendi, M. (2018). Menakar Progresivitas Hukum Wakaf dalam Pengembanganwakaf Uang di Indonesia. Jurnal Ilmu Syariah Dan Hukum, 3(2), 192-204.

Kuncorowati, D. E., Achsani, N. A., \& Hafidhuddin, D. (2018). Manajemen Risiko Wakaf di Dompet Dhuafa. Jurnal Aplikasi Bisnis Dan Manajemen, 4(3), 441453.

https://doi.org/10.17358/jabm.4.3.4 41

Kusnandar, V. B. (2019). Indonesia, Negara dengan Penduduk Muslim Terbesar Dunia.

Lubis, R. H., \& Latifah, F. N. (2019). Analisis Strategi Pengembangan Zakat, Infaq, Shadaqoh dan Wakaf di Indonesia (Analysis of Zakat, Infaq, Shadaqoh and Wakaf Development Strategies in Indonesia). Perisai: Islamic Banking and Finance Journal, 3(1), 45. https://doi.org/10.21070/perisai.v3i 1.1999

Nissa, C. (2017). Sejarah, Dasar Hukum Dan Macam-Macam Wakaf. Jurnal KeIslaman, Kemasyarakatan \& Kebudayaan, 18(2), 205-219.

Novitasari, D. (2018). Pengaruh Wakaf Uang Tunai Produktif terhadap Kesejahteraan Mauquf'alaih BWUT MUI DIY dengan Menggunakan Pendekatan Model Cibest. Jurnal Pendidikan Dan Ekonomi, 7(6), 511-523.

Oktafia, R. (2017). Percepatan Pertumbuhan Usaha Mikro , Kecil Dan Menengah ( UMKM ) Melalui Perkuatan Lembaga Keuangan Mikro Syariah ( Lkms ) Di Jawa Timur, (110), 85-92.

Rafiqi, Y. (2018). Wakaf Benda Bergerak Dalam Perspektif Hukum Islam Dan Perundang-Undangan Di Indonesia. Jurnal Hukum Islam Dan Pranata Sosial, 6(2), 191209.

https://doi.org/10.30868/am.v6i2.3 07

Rajafi, S. H. (2018). Pengelolaan Tanah 
Wakaf Masjid Di Kota Manado. Jurnal Aqlam, 3(2), 281-300.

Rochmiyatun, S. (2018). Problematika Pengelolaan Tanah Wakaf Produktif Berbasis Masjid (Studi Kasus Terhadap Tanah Wakaf Masjid Di Kota Palembang). Jurnal Ekonomi \& Perbankan Syariah, 18(1), 87-104.

Salmawati. (2018). Eksistensi Tanah

Wakaf Dalam Pemanfaatannya Untuk Kemajuan Kesejahteraan Umum. Jurnal Cendekia Hukum, 4(2), 153-165. https://doi.org/10.3376/jch.v4i2.10 6

Senjiati, I. H., Lis Sulistiani, S., \& Mubarok, M. F. R. (2020). Analisis Fikih Wakaf Dan Undang-Undang Nomor 41 Tahun 2004 Tentang Wakaf Terhadap Perolehan Hak Nadzir Pada Pengelolaan Wakaf Uang Nadzir Individu Dikampung Tapos Cikalong Wetan. Jurnal Peradaban Dan Hukum Islam, 3(1), 77-88. https://doi.org/10.29313/tahkim.v3 i1.5661

siwak. (2018). .: Sistem Informasi Wakaf :. Siwak.

Tanjung, H., Suhandi, T., \& Tanzila, W. (2020). Analisis Strategi Pengelolaan Wakaf Uang di Indonesia (Pendekatan Metode
Delphi). Journal of Islamic Economics and Banking, 2(1), 112.

https://doi.org/10.31000/almaal.v2i 1.2592

Tulab, Y. A. S. (2018). Model Pengelolaan Tanah Wakaf di Kota Semarang. Jurnal Studi Dan Penelitian Hukum Islam, 2(1), 63. https://doi.org/10.30659/jua.v2i1.3 570

Yolleng, S. (2018). Pemberdayaan Tanah Wakaf Sebagai Potensi Ekonomi Umat Di Masjid AlMarkaz Al-Islami Makassar. Jurnal Ekonomi Islam, 5(1), 80106.

https://doi.org/10.24252/laamaisyir .v5i1a4

Zahro, M. J. A. P. A. (2020). Implementasi Pendistribusian Wakaf Tunai Sebagai Penunjang Usaha Kecil Menengah di Badan Wakaf Uang \& Badan Wakaf Tunai MUI Yogyakarta. Jurnal Studi Dan Penelitian Hukum Islam, 3(1), 49-66. https://doi.org/10.30659/jua.v3i1.7 554 